Millatī, Journal of Islamic Studies and Humanities

Vol. 4, No. 2, Desember 2019: p. 153-164. DOI: 10.18326/mlt.v4i2. 153-164

p-ISSN : 2541-3627; e-ISSN 2540-9964

Website: http://millati.iainsalatiga.ac.id/index.php/millati/index

\title{
Narration of Islamic Moderation: Counter over Negative Content on Social Media
}

\author{
S. Dinar Annisa Abdullah \\ Institut Agama Islam Negeri (IAIN) Samarinda, Indonesia \\ dinarannisa524@gmail.com \\ Samudera Alfatra \\ Institut Agama Islam Negeri (IAIN) Samarinda, Indonesia
}

\begin{abstract}
This study tires to explore on how far the idea of Islamic moderation was adopted by Duta Damai of East Kalimantan in order to support a campaign of harmony in diversity. Using content analysis, this study tries to describe in depth the information content of Duta Damai community in East Kalimantan. The results of the study indicate that Duta Damai of East Kalimantan conducted counter-narratives of negative content on social media through opinions and statuses on social media, including: (1) alignment of Pancasila ideology with religious teachings, (2) revealing facts and education related to hoaxes (3) multicultural education campaigns and respect for differences, (4) actualization of the contemporary jihad. These four things are in line with the idea of Islamic, meaning that the community actualizes the idea of Islamic moderation in every campaign activity and movement. Through the tagline 'peace is Indonesia', Duta Damai of East Kalimantan want youth groups to actively campaign for the importance of positive speech and behavior and spread peaceful movement, both in the cyberspace and in the real world.
\end{abstract}

Keywords: Duta Damai; Moderation of Islam, Young Generation, Social media.

\begin{abstract}
Abstrak
Penelitian ini berusaha mengkaji sejauhmana gagasan moderasi Islam diadopsi oleh Duta Damai Dunia Maya Kalimantan Timur dalam rangka mendukung kampanyeharmony in diversity. Dengan menggunakan content analysis, penelitian ini berusaha menggambarkan secara mendalam informasi isi media sosial komunitas Duta Damai Dunia Maya Kalimantan Timur. Hasil kajian menunjukkan bahwa Duta Damai melakukan counter-narasi terhadap konten negatif yang ada di media sosialmelalui opini dan status-status di media sosial, meliputi: (1)keselarasaanideologi pancasila dengan ajaran agama, (2) mengungkap fakta dan edukasi terkait hoax, (3) kampanye pendidikan multikultural dan penghargaan terhadap perbedaan, (4) aktualisasi jihad-jihad' kekinian. Keempat hal tersebut sejalan dengan gagasan moderasi Islam, artinya bahwa komunitas tersebut mengaktualisasikan gagasan moderasi Islam dalam setiap kegiatan dan gerakan kampanyenya. Melalui tagline'damai itu Indonesia', Duta Damai menyasar kelompok pemuda untuk secara aktif mengkampanyekan pentingnya tutur kata dan perilaku positif dan menebar gerakan damai, baik di dunia maya maupun dunia nyata.
\end{abstract}

Kata Kunci: Duta Damai, Moderasi Islam, Generasi Muda, Media Sosial. 
Millatī, Journal of Islamic Studies and Humanities, Vol. 4, No. 2, Desember 2019: 153-164

\section{INTRODUCTION}

Apart from being a religion that places a majority position in the midst of the diversity of religions in Indonesia, Islam in this nation is known as a religion that upholds the values of tolerance and nobleness of etiquette. A harmonious relation between substantial teaching of Islam and culture of nation triggers this religion to occupy important position in the hearts of people. Unfortunately, this reality prevails in the pre-reform era backward.

Recently, there have been several religious conflicts and tensions in Indonesian society triggered by the differences in religious understanding among religious groups, ${ }^{1}$ such as riot in Ambon on December 22, 1999. It was caused by the disputes among bandits from Ambon who live in Ketapang and Jakarta, and they are from Muslim and Christian groups. The riot was triggered by the seizure of parking area at club and gambling areas dominated by Christian bandits. This small conflict was more serious since the next day there was news reporting a group of Christian gangs had hit a Muslim and burned a mosque. The conflict still lasts until now.

In October 2017, Baihajar Tualeka was a woman who got involved in a communal violent conflict between Muslims and Christians. She together with a network of other woman's activists held an event called tolerance entitled "Caring for Peace and Togetherness in the Lifestyle of Basudara People." The word "Tolerance Napak" is defined as a form of journey to reflect back the social relations in Ambon which had broken due to conflict. ${ }^{2}$

Modern media also influences the level and way of thinking of modern society. The new era in modern civilization has just faced a multidimensional crisis that threatens global security. Starting from the war in Syria, Rohingya crisis, North Korea's nuclear, Israeli-Palestinian feud which then brought digital devices through certain social media and community news, made the news consumed by the world community without filtering. Receiving news without filtering makes the hoaxes develop and influences the public's perspective and attitude towards those events. ${ }^{3}$

Indonesia indeed becomes a fertile land for perpetrators of violence, radicalism and terrorism. The report by the International NGO Forum on Indonesia Development (INFID) in cooperation with GUSDURIAN network stated that there were approximately 90 thousand twitter

\footnotetext{
${ }^{1} 1$ Iffati Zamimah, "Moderatisme Islam Dalam Konteks Keindonesiaan," in Al-Fanar: Jurnal Ilmu Al-Quran Dan Tafsir Volume 1, Nomor 1 (Juli 2018), p. 77.

2 Ihsan Ali-Fauzi \& Dyah Ayu Kartika, Keluar Dari Ekstremisme: Delapan Kisah "Hijrah" Dari Kekerasan Menuju Binadamai, Jakarta: Pusat Studi Agama dan Demokrasi (PUSAD) Yayasan Wakaf Paramadina, 2018) p. 164165.

3 Jasminto, "Urgensi Teori Andragogi Dalam Memperkuat Visi Moderat Islam Di Indonesia," Proceedings $2^{\text {nd }}$ Annual Conference For Muslim Scholars (Ancoms) Kopertais Wilayah IV Surabaya (April 2018),p. 643.
} 
accounts containing messages of radicalism and extremism within one month. 20 twitter accounts indicated the most frequent tweeting and re-tweeting of radical or extremist messages, with the keywords "unbeliever" as many as 5,173 times and "communist" as many as 995 times. While on Facebook, there are about 884 status updates containing keywords categorized as radical and extremist. On telegram messaging platform, the researcher found the channels@ @hizbuttahiririd (number of members 4,300), @salamdakwah (13,600), @salafyways (4,200), @jalanlurus (586), and ( ) forumkajianislamcikampek (115). Those are channels that often deliver radical messages and extremist. ${ }^{4}$

From January to August 2018, the Ministry of Communication and Information succeeded in blocking 228 terrorism and radicalism sites. Ministry of Communication and Information identified not only terrorism and radicalism sites, but also 62 hoax news contents spread on the internet and social media from August to December 2018. From the negative content identifier machine which is in the Sub-Directorate of Internet Content Control, the Directorate of Control of the Directorate General of Information and Technology found hoax contents related general election in December 2018. The number of hoax contents found was $18 .^{5}$

To minimize the spread of hoaxes, especially those on the internet and social media, the Ministry of Communication and Information Technology (Kemkominfo) was given the authority to restrict access or blocking. In addition, the Ministry of Communication and Information also carried out digital literacy so that the public would be wiser in using the internet and social media, as well as educating the public in identifying them. To anticipate the hoaxes, Kemkominfo is actively conducting narration counter by giving information on clarification and content found as hoaxes through kominfo.go.id and stophoax.id,, as well as through various platforms.

In addition to maximizing the performance of AIS machine to find negative content spread on the internet, the Ministry of Communication and Information actively invited the community in order to be more active in reporting negative content findings on the internet, including hoax content. To report the content, the Ministry of Communication and Information prepared a special site named aduankonten.id. It works by sending quotation or URL account which contains negative

\footnotetext{
4 Mutaya Saroh, "Survei" Pesan Intoleransi Bertebaran di Media Sosial," https://amp.tirto.id/survei-pesan-

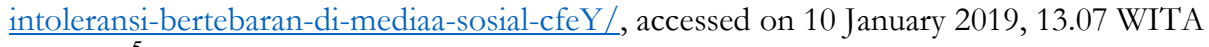

5 Anselmus Bata, https://www.beritasatu.com/fokus/hoax-di-tahun-politik, accessed onb 14 January 2019, 14.12 WITA.
} 
Millatī, Journal of Islamic Studies and Humanities, Vol. 4, No. 2, Desember 2019: 153-164

content. They also invited the community to check and filter the news before spreading the information that still cannot be justified whether it is true or not. ${ }^{6}$

Not only the Ministry of Communication and Information but also the National Counter terrorism Agency is trying to spread of hoaxes. Uniquely, the National Terrorism Overcoming Agency (BNPT) felt that a militaristic approach and intelligence operation based on subversive laws was not successful in dealing with acts of terrorism in Indonesia. Therefore, in the reformation era, Indonesia integrated hard approaches such as law enforcement and soft approaches namely prevention and deradicalization. ${ }^{7}$

In avoiding the acts of intolerance, BNPT through the Center for Peace Media formed a peace squad to carry out counter messaging through social media in the hope that the youths who disagree with radicalism can join the movement. Based on the survey results, it was revealed that the portrait of the majority of younger generation refused any kind of radicalization or acts of violence in the name of religion, arguing that the acts of violence are not in line with religious values, inhumanity, and make the religion bad. Seeing several posts on social media, the younger generation still regards Pancasila to unite differences. Therefore, the concept of Islamic moderation is an alternative to stop the radicalism over negative messages on social media.

Using the method of content analysis, this study aims at exploring how far the role of Duta Damai Dunia Maya Community of East Kalimantan in preventing negative content on social media. Specifically, this research tries to find the point of Islamic moderation ideas through campaign movements conducted by Duta Damai on social media as an effort to support the campaign of harmony in diversity.

\section{DISCUSSION}

\section{The Concept of Islamic Moderation}

Indonesia, with the diversity of its cultures, religions, ethnicity, and languages, declared itself as the nation which has multicultural society. This diversity is recognized by the International World, as said by Australian Prime Minister Malcolm Turnbull at the 2018 Asean-Australia Special Summit, he praised and acknowledged President Joko Widodo's success in leading a multicultural country. He

6 Anselmus Bata, https://www.beritasatu.com/fokus/hoax-di-tahun-politik, accessed on 14 January 2019, 14.12 WITA.

7 Diani Hutabarat, https://kominfo.go.id/content/detail/14342/hingga-agustus-2018-kominfo-blokir-228situs-terorisme/0/sorotan media, accessed on 09 January 2019, 23.50 WITA. 
also said that Indonesia could combine democracy, Islam and moderation. From this diversity, it became a blessing for the Indonesian people. If it can be managed well, calmly and respecting each other, it will become uniqueness and strength for this nation. ${ }^{8}$

Seen from multicultural aspects, especially religion, people can respect all groups, without considering religion, race and ethnicity; this is what so called moderate in the midst of multicultural society. This style of Islam emphasizes on how harmonious atmosphere occurs to the life in diversity, rather than highlighting the right and wrong of a religion, while humanitarian issues such as poverty, health and welfare are ignored. Religious truth is the truth of belief, not empirical truth, so it can waste time and energy, and all can accept the decisions patiently, without having to get involved in anarchist action. Religion is conveyed not forced. ${ }^{9}$

Islam as a peaceful religion has eminence that its teachings are completely balanced. This term appears as an antithesis of the emergence of radical phenomenon in understanding and executing the teachings or religious messages. The meaning of wasatîya terminologically is an attitude that always puts forward the middle values and not excessive. In other words, moderate is tolerance and compromise in seeing differences. This attitude leads to a straight and consistent attitude in finding the middle way to compromise the differences that exist in various aspects of human life. ${ }^{10}$ Moderate is a balance between belief and tolerance as how we have certain beliefs but still have a balanced tolerance for other beliefs. ${ }^{11}$

Moderation is a changing process in which radical individuals and groups accept the principles of democracy, openness, and peace in achieving their political goals. Moderation is one of the cores of deradicalization, namely the efforts to prevent violence by moderating the views so that they are more open, tolerant, and peaceful. ${ }^{12}$

Recently, Islamic moderation has been emphasized as the main focus of Islam Indonesia. It is believed to be a solution to answer various problems of religion and global civilization. It is also the right time for the moderate generation to take more aggressive steps. If radical, extremist, and

8 Muhammad 'Ainul Yaqin, "Dzikir Manâqib: Moderasi Islam di Tengah Masyarakat Multikultural," Proceedings $2^{\text {nd }}$ Annual Conference for Muslim Scholars (AnCoMS)Kopertais Wilayah IV Surabaya (April 2018), p. 949-950.

${ }^{9}$ H. Suparman Syukur, Islam Radikal Vs Islam Rahmah Kasus Indonesia, Teologia, Volume 23, Nomor 1, January 2012), p. 97-98.

${ }^{10}$ Ardiansyah, Islam Wasatiyah Dalam Perspektif Hadis: Dari Konsep Menuju Aplikasi, Jurnal Mutawâtir Vol. 6 No. 2, (July-December 2016), p. 236-237.

11 M. Zaidi Abdad, "Analisis dan Pemetaan Pemikiran Fiqih Moderat di Tmur Tengah dan Relasinya Dengan Gerakan Fiqih Formalis”, in Jurnal Esensia, Vol XII, No.1 (January 2011), p. 42-43.

12 Dr. Suaib Tahir, dkk, Ensiklopedia Pencegahan Terorisme, Cet.III, Jakarta: Badan Nasional Penangggulangan Terorisme, 2018), p. 45. 
Millatī, Journal of Islamic Studies and Humanities, Vol. 4, No. 2, Desember 2019: 153-164

puritan groups speak loudly in line with the acts of violence, then moderate Muslims must speak louder with the acts of peace. ${ }^{13}$ The moderate Muslim movement is one of the best choices for upholding tolerance. Character of rejecting violence, radicalism and terrorism proves that the perspectives of moderate Muslims are closest to the Qur'an. ${ }^{14}$

Islamic moderation is one of the many terminologies that have emerged in the world of Islamic thought, especially in the past two decades. It can even be said that Islamic moderation is an issue of the century. This term appears as an antithesis of the emergence of radical phenomenon in understanding and executing teachings or religious messages. Thus, discussing the discourse of Islamic moderation cannot be separated from talking about Radicalism in Islam. ${ }^{15}$

Islamic moderation is an attitude that always tries to take the middle position of two opposing and excessive attitudes so that one of the two attitudes does not dominate one's mind and attitude. In other words, a moderate Muslim is a Muslim who gives the value or opposing aspect. As a human - whoever he is - is not able to escape from the influence and bias, whether the influence of tradition, mind, family, age or place, then it is impossible to represent or offer full moderation in the real world. Only God can do that. ${ }^{16}$

The concept of moderation in question is a concept that bridges between the rigid fundamental thought and the over-acting liberal thought. Some characteristics of the use of idea on moderation in the context of Indonesian Islam includes: 1) ideology without violence in spreading Islam; 2) adopting a modern way of life with all its derivatives, including science and technology, democracy, human rights and the like; 3) the use of rational thinking; 4) contextual approach in understanding Islam, and (5) the characteristics of a society that has attitude of tolerance, harmony and cooperation among religious groups. ${ }^{17}$

With this character, moderate Islam is those who have a tolerant, harmonious and cooperative attitude with different religious groups. This is good character for Indonesian moderate

${ }^{13}$ Khlaed Abou El-Fadl, Selamatkan Islam dari Muslim Puritan, terj. Helmi Mustofa (Jakarta: Serambi, 2005), p.343.

${ }^{14}$ H. Suparman Syukur, Islam Radikal Vs Islam Rahmah Kasus Indonesia,Teologia, Volume 23, Nomor 1, January 2012), p. 97-98.

${ }^{15}$ Asep Abdurrohman, Eksistensi Islam Moderat dalam Perspektif Islam, Jurnal Pendidikan Agama Islam, Volume 2/Nomor 2, (August 2017), p.131.

16 Nurul Faiqah dan Toni Pransiska, Radikalisme Islam Vs Moderasi Islam: Upaya Membangun Wajah Islam Indonesia Yang Damai, Al-Fikra: Jurnal Ilmiah Keislaman, Vol. 17, No. 1, (January-June, 2018), p. 48.

17 Sauqi Futaqi, “Konstruksi Moderasi Islam (Wasathiyyah) Dalam Kurikulum Pendidikan Islam," Proceedings $2^{\text {nd }}$ Annual Conference for Muslim Scholars (AnCoMS)Kopertais Wilayah IV Surabaya (April 2018), p. 532. 
Islam, which is more theological in meaning, than the politics that is often discussed by the United States when interpreting moderate Islam. Therefore, the moderate understanding above is a necessity, especially in the context of Indonesia. The understanding of moderate Islam is actually the essence of Islam itself. $^{18}$

\section{Duta Damai Dunia Maya of East Kalimantan}

Duta Damai Dunia Maya is one of soft prevention communities established by BNPT to counter terrorism and became balance of negative content in cyberspace. The community has existed since 2016 with 780 peace squads spread across 13 provinces in Indonesia, including the province of East Kalimantan. Duta Damai is a collection of cool, creative, and innovative young people who have a strong passion to stop the spread of negative content that contains expressions of hatred, hostility and violence in the cyberspace and the real world, and are oriented towards the common good and for the integrity and unity of the Republic of Indonesia.

Duta Damai is a volunteer who joins voluntarily, no coercion, and purely because they want to contribute to this country, as well as supportive group that provide support for policies made by BNPT, especially those related to peace campaigns, both in cyberspace and in peaceful communities spread throughout Indonesia. Although it was formed by BNPT, this Duta Damai is independent and is not bound by the anti-terrorism state agency. Youths with different skill and background are united by the same vision that is flooding the cyberspace with positive and peaceful content so that the development of negative content and radicalism can be reduced. The focus of Duta Damai is to be the senders of peaceful messages. Duta Damai doesn't like hate speech and hostility agitation.

The struggle to fight negative content in cyberspace is not only the task of Duta Damai, but also all elements of society. Duta Damai is only a small part of the effort to flood cyberspace with positive and peaceful content so that the development of negative and radical content can be reduced. By being creative and productive, they will continue to explore and develop creativity to spread peaceful messages in cyberspace. They will also become productive youths, so their works can be enjoyed and useful for many people. ${ }^{19}$

18 Darlis, Mengusung Moderasi Islam Di Tengah Masyarakat Multikultural, Rausyan Fike: Jurnal Studi Ilmu Ushuluddin Dan Filsafat, Vo.13 No.2 (2017), p. 232.

19 Tim Pusat Media Damai, Panduan Menjadi Duta Damai Dunia Maya, Cet.II, (Jakarta: Pusat Media Damai (PMD) BNPT, 2017), p. 14-17. 
Millatī, Journal of Islamic Studies and Humanities, Vol. 4, No. 2, Desember 2019: 153-164

Based on the latest survey results on November 23, 2018, it was found that there were 362 uploaded status on Instagram and 333 tweets on the Duta Damai twitter account with five different accounts in four months. The community uploaded 105 posts on the websites in the form of news, peaceful opinion, argumentation, comic, and also video. Likewise on the telegram messaging platform, there is BNPT Duta Damai channel with 386 members and 2,414 media containing Duta Damai's activities, messages of peace, anti-radicalism, and non-violence, or just sharing things related to issues.

It is known that every week the members of the community are given themes related to issues in cyberspace, and then they present articles in the heading column and opinion columns periodically about the substance of life with values of peace and tranquility, the importance of togetherness and brotherhood, and unity in diversity. Among the hundreds of uploaded status, Duta Damai have classified them into several things, namely (1) explaining the harmony of Pancasila ideology with religious teachings, (2) revealing facts and education related to hoaxes, (3) multicultural education campaigns and respecting the differences, (4) ) and the actualization of up to date jihad.

The response of netizen also varied, like supporting everything that was uploaded by the community, defending the homeland, as well as giving peaceful greetings. Interestingly, many netizen want to join the community, but it was responded by Duta Damai that to spread peace in cyberspace does not have to be a Duta Damai because it is our duty as society of Indonesia to create peace.

\section{Narration of Moderation in the Campaign Movement of Duta Damai Dunia Maya Community of East Kalimantan}

On the cyberspace, radicalism is spread through narration of hatred and intolerance that unconsciously poison one's thoughts. This is exacerbated by the lack of resistance against negative campaigns that are widely spread. Counter-narration is a very important thing to do so that people understand the issue clearly and intactly, and is not misled by hoaxes. The vision of Duta Damai is to fight negative issues in cyberspace.

According to Irfan Yusuf, currently to instil the understanding of radicalism in cyberspace is dedicated to adolescents because they are active users of social media and are easily influenced by new things. Therefore, he expressed his opinion that what youth must do is to strive for peace. The following is Irfan Yusuf's opinion as East Kalimantan Duta Damai published in the site http:/ / etam.dutadamai.id/remaja-berjihad-dengan-cara-apa/: 
Narration of Islamic Moderation:..... (S. Dinar Annisa Abdullah and Samudera Alfatra.)

... "In what way? The best struggle in this case is to work for religion, nation and state. If we are able to work in the field of writing, then let's write the positive things on religion, nation and state. If we are active in the field of art, for example singing, let's sing our national songs as a proof of our love to Indonesia. So, when someone or a group of people tries to influence you to get involved in terrorist networks in the name of jihad, then answer loudly NO. Then they will do anything in order you to join them, then answer loudly NO, I STILL LOVE THE NATION AND STATE OF INDONESIA WHICH IS RICH OF TRIBES, RELIGION, AND RACE. "

Specifically, the idea of Islamic moderation is illustrated through the following five points: First, the sentence "when there is a person or group of people who influence you to get involved in terrorism networks in the name of jihad, then answer loudly NO,". It contains indicators that the community accepts ideological principles in spreading religion without any violence and coercion. It is true that all religions teach compassion, peace and harmony.

Second, it was explained earlier that Duta Damai is a collection of cool, creative, and innovative youths who have a strong passion to stop the spread of negative content in cyberspace. It means that they have adopted a modern way of life in terms of technology. The community spreads positive content through websites, Facebook, Twitter, Instagram and YouTube.

Third, Duta Damai prioritize reason and knowledge rather than the emotions seen in the sentence "Then they will do anything in order you to join them, then answer loudly NO, I STILL LOVE THE NATION AND STATE OF INDONESIA WHICH IS WIRCH OF TRIBE, RELIGION , AND RACE. " it means that the community is not easily emotional in both terms nation and religion.

Fourth, if radical groups understand the jihad as one's obligation to fight physically against unbelievers who don't comply with Allah's commands, then the community must understand the true meaning of jihad and is adjusted with the current situation in society and state. Duta Damai actualizes the temporary jihad, such as contemporary proselytizing, online proselytizing, and millennial proselytizing in order to transfer Islamic moderation and nationalization in order to keep Unitary State of the Republic of Indonesia. This is reflected in the sentence "The best jihad in this case is to work for religion, nation and state," meaning that they understand the meaning of religion comprehensively and contextually. 
Millatī, Journal of Islamic Studies and Humanities, Vol. 4, No. 2, Desember 2019: 153-164

Fifth, the opinions campaigned by Duta Damai on social media are to invite the importance of maintaining tolerance, harmony and cooperation among religious groups. The attribute of tolerance is reflected in every posts that never touches on tribes, religions and race. They know that diversity is natural and absolute, so they want harmony to be created in life of nation and state. For example, the tweet on twitter of @dutadamaietam "The land of Indonesia has been permitted to be stepped on by differences. This has already been completed, so it is illogical when the differences are utilized as political propaganda tools to divide the unity and integrity of the nation." 20

Based on the results of analysis, it is known that the community has actualized the idea of Islamic moderation in all activities to prevent the radicalism and violence on social media by means of counter-narration. Through the tagline 'Peace is Indonesia', Duta Damai want the youth groups to actively campaign the importance of positive behavior and spread the peaceful movement, both in cyberspace and in the real world. ${ }^{21}$ This attitude is clearly in line with the characteristics of moderate Islam. $^{22}$

\section{CONCLUSION}

Based on the results of previous studies and discussion, researchers draw some conclusions that Duta Damai Dunia Maya of East Kalimantan are (1) accepting ideological principles in spreading religion without violence; (2) adopting modern ways of life, such as science and technology, democracy, and human rights; (3) prioritizing reason and knowledge over emotions; (4) in understanding religion, they understand it contextually and comprehensively; (5) through the community, the hope is that Indonesia can become an example for other countries in terms of harmony, tolerance, and cooperation among religions.

The efforts conducted by the community are to counter negative narration on social media such as explaining the harmony of Pancasila ideology and religion, uncovering facts and education related to hoaxes, conducting multicultural education campaigns and respecting differences, and

20 Etam Duta Damai,https://twitter.com/dutadamaietam/status/1030316461724585984, accessed on 23 November 2018, 12.46 WITA.

${ }^{21}$ Prof. Dr. Irfan Idris, MA, Membumikan Deradikalisasi: Sof Approach Model Pembinaan Terorisme dari Hulu ke Hilir Secara Berkesinambungan, (Jakarta: Daulat Perss, 2017), p. 328.

22 Fata Asyrofi Yahya, "Meneguhkan Visi Moderasi Dalam Bingkai Etika Islam Relevansi Dan Implikasi Edukatifnya," dalam Proceedings $2^{\text {nd }}$ Annual Conference For Muslim Scholars (Ancoms)Kopertais Wilayah IV Surabaya (April 2018), p, 472. 
Narration of Islamic Moderation:..... (S. Dinar Annisa Abdullah and Samudera Alfatra.)

actualizing contemporary jihad. . These four things are in line with the idea of Islamic moderation, meaning that the community actualizes the idea of Islamic moderation in all activities.

\section{REFERENCES}

Abdad, M. Zaidi. 2011. Analisis dan Pemetaan Pemikiran Fiqih Moderat di Tmur Tengah dan Relasinya Dengan Gerakan Fiqih Formalis.Jurnal Esensia, Vol. XII, No. 1 January.

Abdurrohman, Asep. 2017. Eksistensi Islam Moderat dalam Perspektif Islam.Jurnal Pendidikan Agama Islam,Vol. 2, No. 2 August.

Ardiansyah. 2016. Islam WasatÎyah Dalam Perspektif Hadis: Dari Konsep Menuju Aplikasi.Jurnal Mutawâtir, Vol. 6, No. 2 Desember.

Bata, Anselmus. 2019, Januari 6. Hoax di Tahun Politik. From https://www.beritasatu.com/fokus/hoax-di-tahun-politik.

Darlis. 2017.Mengusung Moderasi Islam Di Tengah Masyarakat Multikultural.Rausyan Fikr: Jurnal Studi Ilmu Ushuluddin Dan Filsafat, Vol. 13, No. 2.

El-Fadl, Khlaed Abou. 2005.Selamatkan Islam dari Muslim Puritan, terj. Helmi Mustofa. Jakarta: Serambi. Etam Duta Damai. 2018. From https://twitter.com/dutadamaietam/status/1030316461724585984. Faiqah, Nurul dan Toni Pransiska. 2018.Radikalisme Islam Vs Moderasi Islam: Upaya Membangun Wajah Islam Indonesia Yang Damai.Al-Fikra: Jurnal Ilmiah Keislaman, Vol. 17, No. 1 June.

Fauzi, Ihsan Ali dan Dyah Ayu Kartika.2018. Keluar Dari Ekstremisme: Delapan Kisah "Hijrah" Dari Kekerasan Menuju Binadamai. Jakarta: Pusat Studi Agama dan Demokrasi (PUSAD) Yayasan Wakaf Paramadina.

Futaqi, Sauqi. 2018. Konstruksi Moderasi Islam (Wasathiyyah) Dalam Kurikulum Pendidikan Islam:Proceedings $2^{\text {nd }}$ Annual Conference for Muslim Scholars (AnCoMS)Kopertais Wilayah IV Surabaya, 21-22 April 2018 (p. 591).

Hutabarat, Diani. 2018, September 9. Hingga Agustus 2018, Kominfo Blokir 228 Situs Terorisme. From https://kominfo.go.id/content/detail/14342/hingga-agustus-2018-kominfo-blokir-228situs-terorisme/0/sorotan media.

Idris, Irfan. 2017.Membumikan Deradikalisasi: Sof Approach Model Pembinaan Terorisme dari Hulu ke Hilir Secara Berkesinambungan.Jakarta: Daulat Perss.

Jasminto. 2018. Urgensi Teori Andragogi Dalam Memperkuat Visi Moderat Islam Di Indonesia:Proceedings $2^{\text {nd }}$ Annual Conference For Muslim Scholars (Ancoms)Kopertais Wilayah IV Surabaya, 21-22 April 2018 (p. 643). 
Millatī, Journal of Islamic Studies and Humanities, Vol. 4, No. 2, Desember 2019: 153-164

Saroh, Mutaya. 2017, Januari 6. Survei" Pesan Intoleransi Bertebaran di Media Sosial. Diterima dari https://amp.tirto.id/survei-pesan-intoleransi-bertebaran-di-mediaa-sosial-cfeY.

Syukur, Suparman. 2012. Islam Radikal Vs Islam Rahmah Kasus Indonesia.Teologia, Vol. 23, No. 1 January.

Tahir, Suaib, dkk.2018. Ensiklopedia Pencegahan Terorisme, $3^{\text {rd }}$ printed. Jakarta: Badan Nasional Penangggulangan Terorisme.

Tim Pusat Media Damai. 2017.Panduan Menjadi Duta Damai Dunia Maya, $2^{\text {nd }}$ printed. Jakarta: Pusat Media Damai (PMD) BNPT.

Yahya, Fata Asyrofi. 2018. Meneguhkan Visi Moderasi Dalam Bingkai Etika Islam Relevansi Dan Implikasi Edukatifnya:Proceedings $2^{\text {nd }}$ Annual Conference For Muslim Scholars (Ancoms)Kopertais Wilayah IV Surabaya, 21-22 April 2018 (p. 472).

Yaqin, Muhammad 'Ainul. 2018. Dzikir Manâqib: Moderasi Islam di Tengah Masyarakat Multikultural:Proceedings $2^{\text {nd }}$ Annual Conference for Muslim Scholars (AnCoMS)Kopertais Wilayah IV Surabaya, 21-22 April 2018 (p. 949-950).

Zamimah, Iffati. 2018. Moderatisme Islam Dalam Konteks Keindonesiaan. Al-Fanar: Jurnal Ilmu AlQuran Dan Tafsir,Vol. 1, No. 1 July, 